\title{
An Alternative Approach to Aminodiols from Baylis-Hillman Adducts. Stereoselective Synthesis of Chloramphenicol, Fluoramphenicol and Thiamphenicol
}

\author{
Cristiano R. Mateus and Fernando Coelho*
}

\author{
Instituto de Química, Universidade Estadual de Campinas, CP 6154, 13083-970 Campinas - SP, Brazil
}

\begin{abstract}
Descrevemos aqui uma nova interpretação para a espectros de banda larga da síntese estereosseletiva de antibióticos de adutos Baylis-Hillman. A estrategia é baseada na preparação de um enocarbamato diretamente do aduto Baylis-Hillman, usando um rearranjo de Curtius. A hidroboração estereosseletiva fornece uma mistura de aminoalcools diasteroisomeros (syn e anti). Após separação cromatográfica, o diasteroisomero syn foi diretamente transformado no antibiótico.
\end{abstract}

We describe herein a new approach for the stereoselective synthesis of broad spectrum antibiotics from Baylis-Hillman adducts. The strategy is based on the preparation of an ene-carbamate directly from a Baylis-Hillman adduct using a Curtius rearrangement reaction. Stereoselective hydroboration furnished a mixture of diastereoisomeric aminoalcohols (syn and anti). After chromatographic separation, the syn diastereoisomer was directly transformed into the antibiotics.

Keywords: chloramphenicol, Baylis-Hillman, fluoramphenicol, thiamphenicol, $\alpha$-hydroxymethylketones

\section{Introduction}

The indiscriminate use of antibiotics in the Western World for the treatment of innumerous infectious diseases has caused as a principal consequence, the appearance of several microorganism species with drug multiresistance. ${ }^{1}$ One of the most obvious strategies to overcome this problem is the utilization of more potent antibiotics but these can cause undesirable effects to patients. In the last few years some older antibiotics have being reintroduced as therapeutics for the treatment of infections caused by drug-multiresistant microorganisms. Among these antibiotics chloramphenicol and its derivatives appear as interesting alternatives. ${ }^{2}$ Due to toxicological problems, these antibiotics were banned from routine usage and their clinical use was restricted to some specific infectious diseases. Recently several papers ${ }^{3}$ and patents ${ }^{4}$ reported the utilization of chloramphenicol and its derivatives as valuable options for the treatment of some infectious disease with the toxicity of these drugs being under reinvestigation.

Chloramphenicol is the first example of an antibiotic discovered through screening of soil microorganisms ${ }^{5}$ and is also the only example of this class of therapeutical compound

\footnotetext{
* e-mail: coelho@iqm.unicamp.br
}

which was commercialized (Figure 1). ${ }^{6}$ There are in the literature numerous papers describing the racemic and asymmetric total syntheses of chloramphenicol and its derivatives, some of them published in the last five years. ${ }^{7-10}$<smiles>[R]C(=O)N[C@@H](CO)[C@@H](O)c1ccc([R])cc1</smiles>
1, $\mathrm{R}=\mathrm{NO}_{2} \quad \mathrm{X}=\mathrm{Cl}-$ Chloramphenicol
2, $\mathrm{R}=\mathrm{NO}_{2} \quad \mathrm{X}=\mathrm{F}$ - Fluoramphenicol
3, $\mathrm{R}=\mathrm{SO}_{2} \mathrm{CH}_{3} \mathrm{X}=\mathrm{Cl}$ - Thiamphenicol

Figure 1. Chloramphenicol (1) and its synthetic derivatives.

Natural chloramphenicol and also its derivatives have two asymmetric centers with absolute configuration $(R, R)$ and syn relative stereochemistry. Although showing decreased antibiotic properties, the racemic mixture is also biologically active, with the anti diastereoisomer being completely inactive. ${ }^{7}$

Recently our research group reported a strategy to prepare 2-amino-1,3-diols from Baylis-Hillman adducts, ${ }^{11}$ which has permitted the synthesis of an oxazolidinone core which exhibited antibiotic properties. An adaptation of this strategy was used recently by us in the synthesis of some substituted tetrahydroisoquinolinones. ${ }^{12}$ 
Based on a research program focused on the demonstration of the synthetic versatility of BaylisHillman adducts ${ }^{13,14}$ as substrates for the synthesis of natural products, we describe herein an alternative approach to directly prepare aminodiols. The stereoselective synthesis of chloramphenicol, fluoramphenicol and thiamphenicol exemplifies the versatility of this strategy.

\section{Results and Discussion}

1,2- and 1,3-Aminoalcohol moieties are ubiquitous substructures associated with biologically active natural products. ${ }^{15}$ Owing to their biological importance and synthetic relevance, there are in the literature several approaches to prepare them. ${ }^{15}$ In a previous communication, ${ }^{11}$ we described an approach to prepare 1,3 aminoalcohols, in which the insertion of the nitrogen atom was achieved via a Curtius rearrangement carried out on a derivative obtained from a Baylis-Hillman adduct. Despite the good chemical yields and operational convenience, this sequence was too long. To take advantage of the functionalities exhibited by the Baylis-Hillman adduct, we decided to investigate an alternative, in which the carboxylate group is used directly as substrate for the Curtius rearrangement, as depicted in Scheme 1. This simple modification could improve the synthetic sequence previously described and increased its efficiency.

Based on this retrosynthetic analysis, the antibiotics 1-3 could be prepared from aminoalcohols 4 and 5 by an amidation reaction. These aminoalcohols could potentially be secured by a hydroboration reaction of the ene-carbamates $\mathbf{6}$ and 7. Ene-carbamates $\mathbf{6}$ and 7 could be prepared via a Curtius rearrangement followed by the reaction of intermediate vinyl isocyanates with $t$-butanol. Acrylic acid derivatives could be easily prepared from basic hydrolysis of the Baylis-Hillman adducts $\mathbf{1 0}$ and $\mathbf{1 1}$.

Depending on the stereoselectivity attained in this sequence, the utilization of an enantiomerically pure Baylis-Hillman adduct could allow the development of an asymmetric version of this strategy. Alternatively, hydroboration could be used as an option to control the relative and absolute stereochemistries of $\mathbf{4}$ and $\mathbf{5}$.
Preparation of the Baylis-Hillman adducts and hydrolysis of the ester

Our work was started with the preparation of adducts 10 and 11. Thus, the Baylis-Hillman reaction between methyl acrylate, 4-nitrobenzaldehyde and 4-methylsulfonylbenzaldehyde, in the presence of DABCO and ultrasound, gave the corresponding adducts with $97 \%$ and $95 \%$ yields, respectively. ${ }^{16}$ To achieve these chemical yields different experimental conditions were tested, which are summarized in Table 1.

The use of methyl acrylate as solvent or polar solvent such as acetonitrile furnished better yields as well as a significant decrease in the reaction time. These experimental conditions can be easily scaled up to $10 \mathrm{~g}$ or more of aldehyde.

To facilitate the Curtius rearrangement ${ }^{17}$ adducts $\mathbf{1 0}$ and $\mathbf{1 1}$ were treated with tert-butyldimethylsilyl triflate in dichloromethane and triethylamine to give the silylated ethers $\mathbf{1 2}$ and 13, in almost quantitative chemical yield (> 99\%). The crude ethers, used without additional purification, were treated with $\mathrm{LiOH}$, in a mixture of acetonitrile: $\mathrm{H}_{2} \mathrm{O}(1: 1)$ at $40-50{ }^{\circ} \mathrm{C}$, to provide acids 8 and 9, in $96 \%$ and $90 \%$ yields, respectively (Scheme 2).

The purities obtained for both acids were high enough to allow their direct utilization in the next steps (Scheme 2).

Table 1. Experimental conditions for Baylis-Hillman reaction

\begin{tabular}{|c|c|c|c|}
\hline $\begin{array}{l}\mathrm{R}=\mathrm{NO}_{2} \\
\mathrm{R}=\mathrm{SO}_{2} \mathrm{CH}_{3}\end{array}$ & $\begin{array}{l}10, R= \\
11, R=\end{array}$ & & \\
\hline \multirow[t]{2}{*}{ Aldehyde } & \multicolumn{2}{|c|}{ Experimental Condition } & Yield $(\%)$ \\
\hline & Solvents & time $(\mathrm{h})$ & \\
\hline \multirow[t]{2}{*}{$4-\mathrm{NO}_{2} \mathrm{Ph}$} & $\mathrm{CH}_{2} \mathrm{Cl}_{2}$ & 16 & 90 \\
\hline & methyl acrylate & 4 & 97 \\
\hline \multirow[t]{4}{*}{ 4- $\mathrm{CH}_{3} \mathrm{SO}_{2} \mathrm{Ph}$} & $\mathrm{CH}_{2} \mathrm{Cl}_{2} / \mathrm{CH}_{3} \mathrm{OH}(3: 1)$ & 30 & 5 \\
\hline & $\mathrm{CH}_{2} \mathrm{Cl}_{2} / \mathrm{CH}_{3} \mathrm{OH}(1: 3)$ & 25 & 36 \\
\hline & $\mathrm{CH}_{3} \mathrm{CN}$ & 65 & 70 \\
\hline & $\begin{array}{l}\mathrm{CH}_{3} \mathrm{CN}: \text { methyl } \\
\text { acrylate }(1: 1)\end{array}$ & 27 & 95 \\
\hline
\end{tabular}

${ }^{a}$ yields for isolated and purified products.
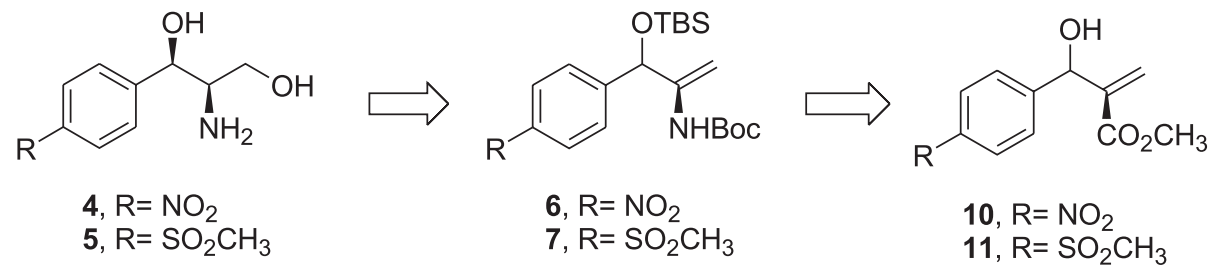

Scheme 1. Retrosynthetic strategy to directly prepare aminoalcohols from Baylis-Hillman adducts. 
<smiles>[R]c1ccc(C(O)C(=C)C(=O)OC)cc1</smiles><smiles>[R]C(=C)C([O+])c1ccc([R])cc1</smiles>

$$
\begin{aligned}
& \text { 10, } \mathrm{R}=\mathrm{NO}_{2} \\
& \text { 11, } \mathrm{R}=\mathrm{SO}_{2} \mathrm{CH}_{3}
\end{aligned}
$$

Scheme 2. Reagents and conditions: a) TBSOTf, $\mathrm{CH}_{2} \mathrm{Cl}_{2}, \mathrm{Et}_{3} \mathrm{~N}, 0^{\circ} \mathrm{C}$ 0 r.t, 4 hs, $99 \%$ (for $\mathbf{1 2}$ and 13); b) $\mathrm{LiOH}, \mathrm{CH}_{3} \mathrm{CN}: \mathrm{H}_{2} \mathrm{O}(1: 1), 40-$ $50{ }^{\circ} \mathrm{C}, 2-4 \mathrm{~h}, 96 \%$ (for 8 ) and $90 \%$ (for $\mathbf{9}$ )

Preparation of ene-carbamates from Baylis-Hillman adducts

To insert the nitrogen atom into this structure, a solution of acids 8 and $\mathbf{9}$ in acetone was treated with ethyl chloroformate and triethylamine for 15 minutes at $0{ }^{\circ} \mathrm{C}$, to give the corresponding anhydrides, which were not isolated. The crude anhydrides were treated with a solution of sodium azide in water $(1 \mathrm{~g} / 3 \mathrm{~mL})$ at $0{ }^{\circ} \mathrm{C}$ for $50 \mathrm{~min}$. After this time, the resulting mixture was refluxed in toluene for $1 \mathrm{~h}$ to give the vinyl isocyanates, which in turn were refluxed in methanol. Unfortunately these ene-carbamates $\mathbf{1 4}$ and $\mathbf{1 5}$ proved to be very unstable to different conditions (acid or base) degrading to a very stable product. A careful analysis of the ${ }^{1} \mathrm{H}$ and ${ }^{13} \mathrm{C}$ NMR spectra showed the formation of the methyl ketones $\mathbf{1 6}$ and 17. Most probably this product was formed by hydrolysis of the ene-carbamate followed by an equilibration step to an imine and hydrolysis as depicted in Scheme 3. This represents the first report concerning the preparation of $\alpha$-hydroxymethyl ketones with the loss of one carbon unit directly from Baylis-Hillman adducts.

To circumvent the high instability of the carbomethyloxy ene-carbamates we decided to intercept the vinyl isocyanates with $t$-butanol in order to prepare the corresponding tert-butyloxycarbonyl ene-carbamate, which was shown to be much more stable, as expected.

Seeking to increase the efficiency of this sequence, we tried to prepare the ene-carbamates by the direct treatment of acids $\mathbf{8}$ and $\mathbf{9}$ with DPPA (diphenyl phosphoryl azide) in toluene under reflux in the presence of triethylamine. Unfortunately, the use of DPPA was unsuccessful although the isomerization through the mixt anhydride proved to be viable.

Preparation of aminoalcohols, determination of relative streochemistry and synthesis of the antibiotics

The hydroboration reaction of ene-carbamates 6 and 7 was carried out using two different boranes, $\mathrm{BH}_{3} \cdot \mathrm{S}\left(\mathrm{CH}_{3}\right)_{2}$ and 9-BBN. Our intention was to evaluate the degree of diastereoselection, since there is a relationship between the size of the borane and the diastereoselectivity. ${ }^{11}$

Ene-carbamates 6 and 7 were treated separately with $\mathrm{BH}_{3} . \mathrm{S}\left(\mathrm{CH}_{3}\right)_{2}$ and $9-\mathrm{BBN}$ in THF, at $0{ }^{\circ} \mathrm{C}$ for $18 \mathrm{~h}$. Then, a 3 mol L-1 solution of $\mathrm{NaOH}$ and $30 \% \mathrm{H}_{2} \mathrm{O}_{2}$ was added to the reaction mixture at $0{ }^{\circ} \mathrm{C}$ for $2 \mathrm{~h}$ to give the corresponding aminoalcohols (18a,b/19a,b), as a mixture of diastereoisomers, in $65 \%$ yield. The results are summarized in Table 2.

The presence of two large substituents directly bonded to the double bond (TBS and Boc) could perhaps explain the poor diastereoisomeric ratio observed for both boranes. Due to the size of these substituents the approximation of $\mathrm{BH}_{3}$ apparently occurs at both faces, with a discrete preference for the $R e$ face. Otherwise, when the size of the boron reagent was increased we observed a complete loss of diastereoselectivity. To check this alternative, ene-carbamate 6 was treated with TBAF/THF and the resulting alcohol was

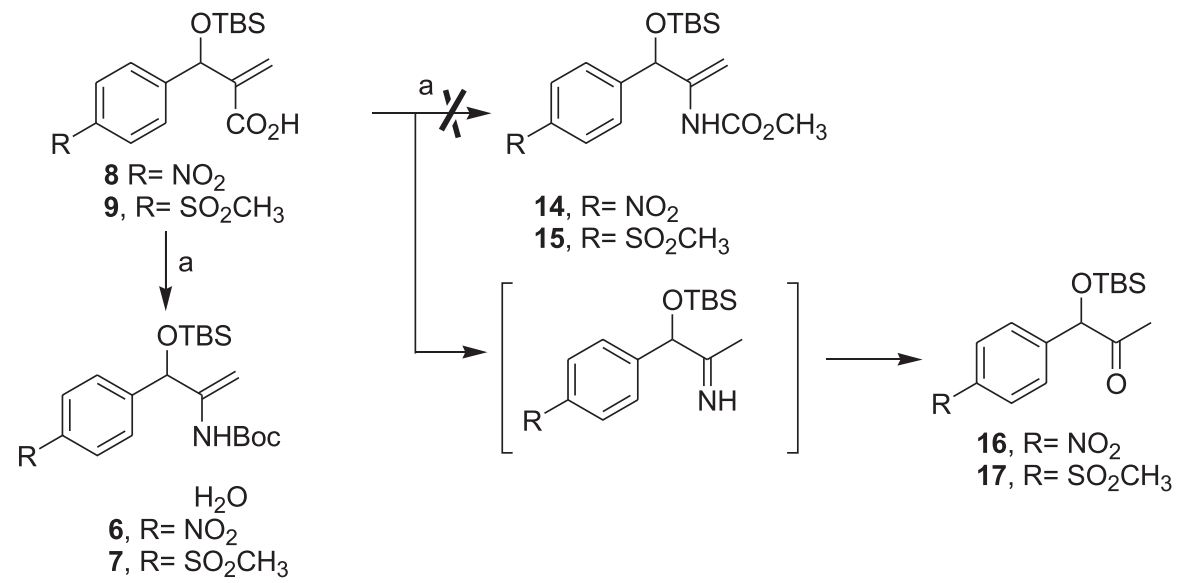

Scheme 3. Reagents and conditions: a) i. ethyl chloroformate, acetone, $\mathrm{Et}_{3} \mathrm{~N}, 0{ }^{\circ} \mathrm{C}, 15 \mathrm{~min}$.; ii. $\mathrm{NaN}_{3}, \mathrm{H}_{2} \mathrm{O}, 0{ }^{\circ} \mathrm{C}, 50$ min, then toluene, reflux, 1 h; iii. $\mathrm{MeOH}$, reflux, $18 \mathrm{~h}, 60 \%$ overall yield or $t-\mathrm{BuOH}$, reflux, $18 \mathrm{hs}, 52 \%$ overall yield (for both cases). 
used as substrate for a hydroboration reaction. Unfortunately, no significant change in the diastereoselectivity ratio has been observed ( 1.8: 1.0; syn: anti).

The diastereoisomers were readily separated, by conventional silica gel column chromatography. At this stage of the work, the relative configuration of the diastereoisomers should be determined before going on with the strategy. In effect, we had two alternatives to evaluate: determine the relative stereochemistry or finish the total synthesis of the antibiotics and compare our spectral and physico-chemical data with those available in literature. From our point of view the second option was the easier way to finish the synthesis.

The major diastereoisomer 18a was treated with $\mathrm{HCl}$ $\left.(6 \mathrm{~mol} \mathrm{~L})^{-1}\right)$ in ethyl acetate $(1: 1)$ at room temperature for 3 $\mathrm{h}$ to give the corresponding amino alcohol in $98 \%$ yield, after purification by ion exchange chromatography.

The results could be rationalized as shown in Figure 2 below. $^{18}$

The purified aminoalcohol 4 was then refluxed in methyl dichloroacetate for $3 \mathrm{~h}$ to provide the $\mathrm{N}$-acetylated product in $79 \%$ yield. All the spectroscopic and physical data of this compound are completety compatible with those described for a synthetic sample of Chloramphenicol (1). Based on this data the major product obtained in the hydroboration step is that with the relative syn stereochemistry. ${ }^{18}$ To finish the synthesis of Fluoramphenicol

Table 2. The hydroboration reaction of ene-carbamates

\begin{tabular}{|c|c|c|c|}
\hline \multirow{2}{*}{$\begin{array}{l}\quad \begin{array}{l}\text { 6, } \mathrm{R}=\mathrm{NO}_{2} \\
\text { 7, } \mathrm{R}=\mathrm{SO}_{2} \mathrm{CH}_{3}\end{array} \\
\text { Borane }\end{array}$} & $\begin{array}{l}18 a, R=N_{2} \\
19 a, R=S_{2} C_{3}\end{array}$ & \multicolumn{2}{|c|}{$\begin{array}{l}18 b, R=\mathrm{NO}_{2} \\
19 b, R=\mathrm{SO}_{2} \mathrm{CH}_{3}\end{array}$} \\
\hline & Carbamate & syn $:$ ant $^{\mathrm{b}}$ & Yield (\%) \\
\hline $\mathrm{BH}_{3} \cdot \mathrm{S}\left(\mathrm{CH}_{3}\right)_{2}$ & 6 & $2: 1$ & 65 \\
\hline 9-BBN & 6 & $1: 1.2$ & 36 \\
\hline $\mathrm{BH}_{3} \cdot \mathrm{S}\left(\mathrm{CH}_{3}\right)_{2}$ & 7 & $1.5: 1$ & 65 \\
\hline 9-BBN & 7 & $1: 1$ & 40 \\
\hline
\end{tabular}

${ }^{\mathrm{a}} i$. borane, THF, $0{ }^{\circ} \mathrm{C} \mathrm{O}$ r.t.; ii. $3 \mathrm{~mol} / \mathrm{L} \mathrm{NaOH}, \mathrm{H}_{2} \mathrm{O}_{2}, 0{ }^{\circ} \mathrm{C}$ o r.t.; ${ }^{\text {b }}$ the diastereoisomeric ratio was measured by ${ }^{1} \mathrm{H}$ NMR.

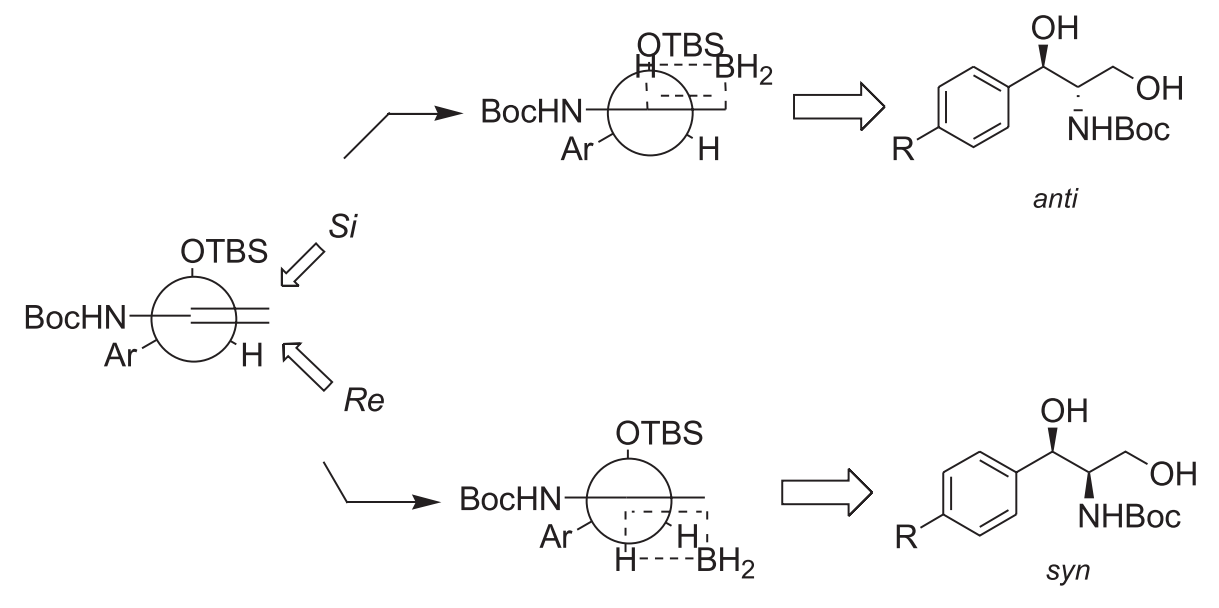

Figure 2. Rationalization to explain the diastereoselectivity observed in the hydroboration reactions.

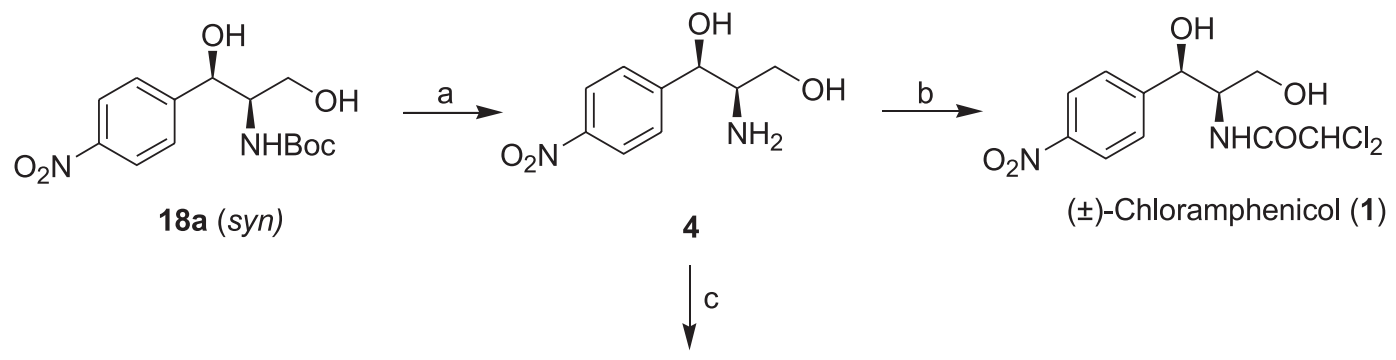<smiles>O=[N+]([O-])c1ccc([C@@H](O)[C@H](CO)NC(F)F)cc1</smiles>

(土)-Fluoramphenicol (2)

Scheme 4. Reagents and conditions: a) Ethyl acetate : $\mathrm{HCl}\left(6 \mathrm{~mol} \mathrm{~L}^{-1}\right)(1: 1)$, r.t., 3 h, 98\%; b) Methyl dichloroacetate, reflux, 3 h, $79 \%$; c) Methyl difluoroacetate, reflux, $4 \mathrm{~h}, 85 \%$. 


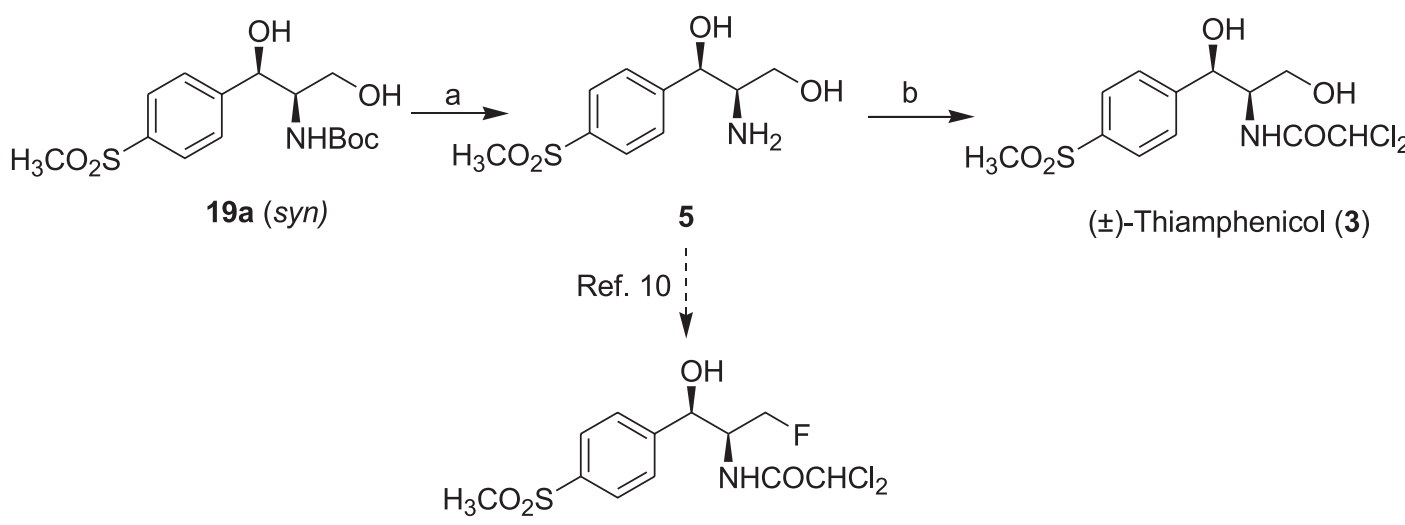

(士)-Florphenicol (20)

Scheme 5. Reagents and conditions: a) Ethyl acetate : $\mathrm{HCl}\left(6 \mathrm{~mol} \mathrm{~L}^{-1}\right)(1: 1)$, r.t., $3 \mathrm{~h}, 90 \%$; b) Methyl dichloroacetate, reflux, $1 \mathrm{~h}, 65 \%$.

(2), the aminoalcohol 4 was refluxed with methyl difluoroacetate for $4 \mathrm{~h}$ to afford $\mathbf{2}$, in $85 \%$ yield (Sheme 4 ).

The same procedure was repeated with the aminoalcohol 19a, which has been treated with a mixture of ethyl acetate and hydrogen chloride to provide the aminoalcohol $\mathbf{5}$, in $90 \%$ yield, after purification by ion exchange chromatographic. The latter was then refluxed with methyl dichloroacetate to give racemic thiamphenicol (3) as the sole product in $65 \%$ yield (Scheme 5). Recently, Wu et al. ${ }^{10}$ have employed aminoalcohol 5 as the intermediate in the total synthesis of florfenicol, representing a formal synthesis of this antibiotic.

All spectroscopic and physical data of thiamphenicol are completely compatible with those available in the literature and with that of a commercial sample.

\section{Conclusion}

We have demonstrated the preparation of some broad spectrum antibiotics from Baylis-Hillman adducts, using a simple and straightforward strategy that can be readily scaled up. ${ }^{20}$

Chloramphenicol and fluoramphenicol were synthesized in 8 steps with overall yields of $20 \%$ and $23 \%$, respectively. Thiamphenicol was also synthesized in 8 steps with an overall chemical yield of $20 \%{ }^{21}$ As it is possible to obtain enantiomerically pure Baylis-Hilman adduct, this sequence could be used as a valuable alternative for the asymmetric synthesis of these antibiotics. ${ }^{22}$

The Baylis-Hillman adducts are easily transformed to $\alpha$-hydroxy-methyl ketones in 3 steps with an overall yield up $74-76 \%$. This generality, as well as the synthetic utility of this method, are under investigation in our laboratory and the results will be described in the due time.

\section{Experimental}

The ${ }^{1} \mathrm{H}$ and ${ }^{13} \mathrm{C}$ spectra were recorded on a Varian GEMINI BB-300 at $300 \mathrm{MHz}$ and $75.4 \mathrm{MHz}$, respectively, or on an Inova instrument at $500 \mathrm{MHz}$ and $125 \mathrm{MHz}$, respectively. The mass spectra were recorded using a HP model 5988A GC/MS with a High Resolution AutospecMicromass/EBE. IR were obtained with a Nicolet model Impact 410. Melting points were measured in open capillary tubes using an Electrothermal model 9100 apparatus and are uncorrected. Yields were determined from GC analyses on a HP6890 equipment with a flame ionization detector, using a HP-5 capillary (crosslinked 5\% phenylmethylsiloxane, $28 \mathrm{~m}$ ) column. Manipulations and reactions were not performed under dry atmospheres or employing dry solvents, unless otherwise specified. Purification and separations by column chromatography were performed on silica gel, using normal or flash chromatography. TLC visualization was achieved by spraying with 5\% ethanolic phosphomolybdic acid and heating. All Baylis-Hillman reactions were sonicated in an ultrasonic cleaner UNIQUE model GA 1000 (1000W, $25 \mathrm{kHz}$ ). Ice was added occasionally to avoid increasing the temperature of the water bath of the ultrasonic cleaner, which was maintained between $35-40{ }^{\circ} \mathrm{C}$. Reagents were purchased from Aldrich, Acros or Lancaster and were used without purification.

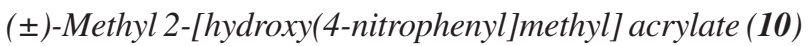

A mixture of 4-nitrobenzaldehyde $(0.75 \mathrm{~g}, 5 \mathrm{mmol})$, methyl acrylate $(5.16 \mathrm{~g}, 5.4 \mathrm{~mL}, 12 \mathrm{eq}$.) and DABCO $(0.36$ $\mathrm{g}, 0.65$ eq.) was sonicated for $4 \mathrm{~h}$, at room temperature. After this time, the reaction mixture was diluted with ethyl acetate $(10 \mathrm{~mL})$ and the organic phase was washed with 
brine $(2 \times 20 \mathrm{~mL})$, dried over $\mathrm{Na}_{2} \mathrm{SO}_{4}$ and evaporated under reduced pressure. The residue was purified by silica gel column chromatography using ethyl acetate : hexane (70: $30)$ as eluent to provide $1.15 \mathrm{~g}(97 \%)$ of $\mathbf{1 0}$ as light yellow amorphous solid, m.p. $73-74{ }^{\circ} \mathrm{C}$, Lit. ${ }^{16} 74{ }^{\circ} \mathrm{C}$; IR (KBr) $v_{\max } / \mathrm{cm}^{-1}: 3511,3108,2959,1698,1624,1518,1444$, 1348, 1293, 1224, 1145, 1094, 983; ${ }^{1} \mathrm{H}$ NMR (300 MHz, $\left.\mathrm{CDCl}_{3}\right) \delta 3.25\left(1 \mathrm{H}, \mathrm{bs}\right.$, exchangeable with $\left.\mathrm{D}_{2} \mathrm{O}\right), 3.74$ (s, $3 \mathrm{H}), 5.63$ (s, 1H), 5.89 (s, 1H), 6.39 (s, 1H), 7.57 (d, 2H, J $8.4 \mathrm{~Hz}), 8.18$ (d, 2H, J 8.4 Hz); ${ }^{13} \mathrm{C} \mathrm{NMR}\left(75 \mathrm{MHz} \mathrm{CDCl}_{3}\right)$ $\delta$ 52.2, 72.6, 123.5, 127.1, 127.2, 140.8, 147.3, 148.5, 166.2; HRMS (70 eV, m/z): $\mathrm{M}^{+\bullet}$ calc. for $\mathrm{C}_{11} \mathrm{H}_{11} \mathrm{NO}_{5}$ 237.06372; Found $\mathrm{M}^{+\bullet} 237.06364$.

\section{(土)-Methyl 2-[hydroxy[4-methanesulfonyl)methyl acrylate} (11)

A solution of 4-methanesulfonylbenzaldehyde (0.92 $\mathrm{g}, 5 \mathrm{mmol})$ and DABCO (0.36 g, 0.65 eq.) in a mixture of methyl acrylate and acetonitrile $(1: 1,20 \mathrm{~mL})$ was sonicated for $27 \mathrm{~h}$ at room temperature. After that, the reaction medium was diluted with ethyl acetate $(100 \mathrm{~mL})$ and the organic layer was washed with brine $(2 \times 20 \mathrm{~mL})$ and dried over $\mathrm{Na}_{2} \mathrm{SO}_{4}$. After solvent evaporation, the residue was purified by silica gel column chromatography using a mixture of ethyl acetate : hexane $(1: 1)$ as eluent to furnish $1.28 \mathrm{~g}(95 \%)$ of a lightly yellow viscous oil. IR (KBr) $v_{\max }$ / $\mathrm{cm}^{-1}$ : 3494, 3020, 2954, 2927, 1049, 1712, 1631, 1439, 1296, 1146, 960; ${ }^{1} \mathrm{H}$ NMR (300 MHz, $\left.\mathrm{CDCl}_{3}\right) \delta 2.99$ (s, $3 \mathrm{H}), 3.69$ (s, 3H), $5.58(\mathrm{~s}, 1 \mathrm{H}), 5.88(\mathrm{~s}, 1 \mathrm{H}), 6.35$ (s, 1H), 7.55 (d, 2H, J 8.4 Hz), 7.83 (d, 2H, J 8.4 Hz); ${ }^{13} \mathrm{C} \mathrm{NMR}(75$ $\left.\mathrm{MHz}, \mathrm{CDCl}_{3}\right) \delta 44.5,52.2,72.6,126.9,127.3,127.4,139.5$, 141.0, 147.6, 166.2; HRMS (70 eV, $m / z): \mathbf{M}^{+\bullet}$ calc. for $\mathrm{C}_{12} \mathrm{H}_{14} \mathrm{O}_{5} \mathrm{~S}$ 270.05620; Found $\mathrm{M}^{+\bullet} 270.05615$.

(土)-Methyl 2[(tert-butyldimethyl silanyloxy)-(4nitrophenyl)methyl]acrylate (12)

To a stirred solution of $\mathbf{1 0}(0.23 \mathrm{~g}, 1 \mathrm{mmol})$ in anhydrous dichloromethane $(5 \mathrm{~mL})$, under dry nitrogen atmosphere, was added triethylamine $(0.25 \mathrm{~g}, 0.34 \mathrm{~mL}, 2.5 \mathrm{mmol})$ and tert-butyldimethylsilyl trifluoromethanesulfonate $(0.39 \mathrm{~g}$, $0.26 \mathrm{~mL}, 1.5 \mathrm{mmol}$ ), at room temperature. After $4 \mathrm{~h}$, the reaction medium was diluted with ethyl acetate $(60 \mathrm{~mL})$ and washed sucessively with $\mathrm{HCl}$ solution $\left(0.5 \mathrm{~mol} \mathrm{~L}^{-1}\right)$, saturated solution of $\mathrm{NaHCO}_{3}$ and brine. The organic phase was dried over anhydrous $\mathrm{Na}_{2} \mathrm{SO}_{4}$ and evaporated. The residue was purified by silica gel column chromatography using a mixture of ethyl acetate : hexane $(5: 95)$ as eluent to provide $12(0.35 \mathrm{~g},>99 \%)$, as a colorless viscous oil. IR (Film) $v_{\max } / \mathrm{cm}^{-1}: 2954,2931,2858,1720,1523,1350$,
1257, 1088, 837; ${ }^{1} \mathrm{H}$ NMR (300 MHz, $\left.\mathrm{CDCl}_{3}\right) \delta-0.074$ (s, $3 \mathrm{H}), 0.065$ (s, 3H), 0.87 (s, 9H), 3.68 (s, 3H), 5.68 (s, 1H), $6.16(\mathrm{~s}, 1 \mathrm{H}), 6.32(\mathrm{~s}, 1 \mathrm{H}), 7.55(\mathrm{~d}, 2 \mathrm{H}, J 8.8 \mathrm{~Hz}), 8.14(\mathrm{~d}, 2 \mathrm{H}$, $J 8.8 \mathrm{~Hz}) ;{ }^{13} \mathrm{C} \mathrm{NMR}\left(75 \mathrm{MHz}, \mathrm{CDCl}_{3}\right) \delta-5.09,-5.03,18.1$, 25.6, 51.8, 71.9, 123.4, 125.0, 127.7, 142.8, 147.2, 150.2, 165.8; HRMS (70 eV, $m / z): \mathrm{M}^{+\bullet}-t$-Bu calc. for $\mathrm{C}_{17} \mathrm{H}_{25} \mathrm{O}_{5} \mathrm{SiN}$ 294.07977; Found $\mathrm{M}^{+\bullet}$ - $t$-Bu 294.080140.

(土)-Methyl 2[(tert-butyldimethyl silanyloxy)-(4methanesulfonylphenyl)methyl]acrylate (13)

To a stirred solution of $11(0.27 \mathrm{~g}, 1 \mathrm{mmol})$ in anhydrous dichloromethane $(5 \mathrm{~mL})$, under dry nitrogen atmosphere, was added triethylamine $(0.2 \mathrm{~g}, 0.27 \mathrm{~mL}, 2.0 \mathrm{mmol})$ and tert-butyldimethylsilyl trifluoromethanesulfonate $(0.39 \mathrm{~g}$, $0.26 \mathrm{~mL}, 1.5 \mathrm{mmol}$ ), at room temperature. After $4 \mathrm{~h}$, the reaction medium was diluted with ethyl acetate $(60 \mathrm{~mL})$ and washed sucessively with $\mathrm{HCl}$ solution $\left(0.5 \mathrm{~mol} \mathrm{~L}^{-1}\right)$, saturated solution of $\mathrm{NaHCO}_{3}$ and brine. The organic phase was dried over anhydrous $\mathrm{Na}_{2} \mathrm{SO}_{4}$ and evaporated. The residue was purified by silica gel column chromatography using a mixture of ethyl acetate : hexane $(5: 95)$ as eluent to provide $\mathbf{1 3}(0.38 \mathrm{~g},>99 \%)$, as a colorless viscous oil. IR (Film) $v_{\max } / \mathrm{cm}^{-1}: 3431,2955,2936,2854,1713,1628$, 1437, 1303, 1248, 1147, 836, 544; ' $\mathrm{H}$ NMR (300 MHz, $\left.\mathrm{CDCl}_{3}\right) \delta-0.096(\mathrm{~s}, 3 \mathrm{H}), 0.044(\mathrm{~s}, 3 \mathrm{H}), 0.86(\mathrm{~s}, 9 \mathrm{H}), 3.02$ (s, $3 \mathrm{H}), 3.67$ (s, 3H), 5.65 (s, 1H), $6.14(\mathrm{~s}, 1 \mathrm{H}), 6.29$ (s, 1H), 7.57 (d, 2H, J 8.0 Hz), 7.84 (d, 2H, J 8.0 Hz); ${ }^{13} \mathrm{C} \mathrm{NMR}(75$ $\mathrm{MHz}, \mathrm{CDCl}_{3}$ ) $\delta-4.96,-4.03,18.2,25.7,44.4,51.8,71.9$, 124.8, 127.1, 127.6, 139.2, 142.7, 148.9, 165.6; HRMS $(70 \mathrm{eV}, m / z): \mathrm{M}^{+\cdot}-t$-Bu calc. for $\mathrm{C}_{18} \mathrm{H}_{28} \mathrm{O}_{5} \mathrm{SSi}-t$-Bu 326.06442; Found $\mathrm{M}^{+\bullet}-t$-Bu 326.06430.

\section{General procedure for the preparation of acids 8 and 9}

To a stirred solution of $\mathbf{1 2}$ or $\mathbf{1 3}(1 \mathrm{mmol})$ in $20 \mathrm{~mL}$ of $\mathrm{CH}_{3} \mathrm{CN}: \mathrm{H}_{2} \mathrm{O}(1: 1)$ was added $\mathrm{LiOH}(0.23 \mathrm{~g}, 10 \mathrm{mmol}, 10$ eq.) The reaction mixture was then warmed up to $40-50{ }^{\circ} \mathrm{C}$ (for 12) or 50-60 ${ }^{\circ} \mathrm{C}$ (for 13) and kept at the same temperature for $4 \mathrm{~h}$. After that, the reaction mixture was concentrated under reduced pressure and the residue was diluted with ethyl acetate $(40 \mathrm{~mL})$. The aqueous phase was extracted twice with ethyl acetate $(40 \mathrm{~mL}$ each time) and finally the organic phases were combined. The solvent was dried over anhydrous $\mathrm{Na}_{2} \mathrm{SO}_{4}$ and evaporated to give an oily residue, which was sufficiently pure to be used in the next steps without additional purification.

(士)-2-[(tert-butyldimethylsilanyloxy)-(4-nitrophenyl)methyl] acrylic acid (8). $0.32 \mathrm{~g}, 96 \%$ yield; IR (Film) $v_{\max }$ ' $\mathrm{cm}^{-1}$ : 3078, 2954, 2931, 2858, 2588, 1697, 1523, 1350, $1257,1088,872,837,779 ;{ }^{1} \mathrm{H}$ NMR $\left[300 \mathrm{MHz}, \mathrm{CO}\left(\mathrm{CD}_{3}\right)_{2}\right]$ 
$\delta-0.02(\mathrm{~s}, 3 \mathrm{H}), 0.11(\mathrm{~s}, 3 \mathrm{H}), 0.90(\mathrm{~s}, 9 \mathrm{H}), 5.80(\mathrm{~s}, 1 \mathrm{H}), 6.18$ $(\mathrm{s}, 1 \mathrm{H}), 6.35(\mathrm{~s}, 1 \mathrm{H}), 7.70(\mathrm{~d}, 2 \mathrm{H}, J 8.8 \mathrm{~Hz}), 8.20(\mathrm{~d}, 2 \mathrm{H}, J 8.8$ $\mathrm{Hz}) ;{ }^{13} \mathrm{C}$ NMR $\left[75 \mathrm{MHz}, \mathrm{CO}\left(\mathrm{CD}_{3}\right)_{2}\right] \delta-5.05,-5.02,18.5$, 25.8, 72.4, 123.6, 124.9, 128.4, 144.0, 147.7, 150.9, 166.2; HRMS $(70 \mathrm{eV}, m / z): \mathrm{M}^{+\bullet}-t$-Bu calc. for $\mathrm{C}_{16} \mathrm{H}_{23} \mathrm{NO}_{5} \mathrm{Si}-t$-Bu 279.0563; Found $\mathrm{M}^{+\bullet}-t$-Bu 279.0560.

( \pm ) - 2 - [ (tert-butyldime thylsilanyloxy) - (4methylsulfonyl)-methyl] acrylic acid (9). $0.33 \mathrm{~g}, 90 \%$ yield; IR (Film) $v_{\text {max }} / \mathrm{cm}^{-1}: 3484,2955,2929,2857,1694$, $1626,1471,1303,1254,1150,1087,957,836,776 ;{ }^{1} \mathrm{H}$ $\mathrm{NMR}\left(300 \mathrm{MHz}, \mathrm{CDCl}_{3}\right) \delta-0.09(\mathrm{~s}, 3 \mathrm{H}), 0.046(\mathrm{~s}, 3 \mathrm{H}), 0.86$ (s, 9H), $3.03(\mathrm{~s}, 3 \mathrm{H}), 5.63(\mathrm{~s}, 1 \mathrm{H}), 6.25(\mathrm{~s}, 1 \mathrm{H}), 6.44(\mathrm{~s}, 1 \mathrm{H})$, 7.57 (d, 2H, J 8.0 Hz), 7.84 (d, 2H, J 8.0 Hz); ${ }^{13} \mathrm{C}$ NMR $(75$ $\left.\mathrm{MHz}, \mathrm{CDCl}_{3}\right) \delta-4.93\left(2 \times \mathrm{CH}_{3}\right), 18.1\left(3 \times \mathrm{CH}_{3}\right), 25.6,44.5$, 71.6, 127.0, 127.6, 139.2, 142.3, 148.6, 169.5, 171.0. HRMS $(70 \mathrm{eV}, m / z): \mathrm{M}^{+*}-t$-Bu calc. for $\mathrm{C}_{17} \mathrm{H}_{26} \mathrm{O}_{5} \mathrm{SSi}-t$-Bu 312.04877; Found $\mathrm{M}^{+\bullet}-t$-Bu 312.04870.

\section{General procedure for the preparation of $\alpha$-hydroxymethyl} ketones 16 and 17

To stirred solutions of acids 8 and $9(1 \mathrm{mmol})$ in $10 \mathrm{~mL}$ of acetone, at $0{ }^{\circ} \mathrm{C}$, was added anhydrous triethylamine $(0.20 \mathrm{~g}, 0.26 \mathrm{~mL}, 2$ eq. $)$ and ethyl chloroformate $(0.16 \mathrm{~g}$, $0.143 \mathrm{~mL}, 1.5$ eq.). The resulting solution was stirred for 15 minutes at $0{ }^{\circ} \mathrm{C}$, followed by the addition of a solution of sodium azide $(0.1 \mathrm{~g})$ in water $(0.3 \mathrm{~mL})$. After $1 \mathrm{~h}$ at $0{ }^{\circ} \mathrm{C}$, the reaction mixture was diluted with dichloromethane (30 $\mathrm{mL})$ and the organic layer was washed with distilled water $(10 \mathrm{~mL})$, brine $(10 \mathrm{~mL})$ and dried over anhydrous $\mathrm{Na}_{2} \mathrm{SO}_{4}$. The solvent was evaporated under reduced pressure. Then, the oily residue was refluxed in anhydrous toluene $(10 \mathrm{~mL})$ for $1 \mathrm{~h}$. After this time, the solvent was removed under reduced pressure and the residue was refluxed in water $(10 \mathrm{~mL})$ for $2 \mathrm{~h}$. The reaction mixture was then diluted with dichloromethane $(40 \mathrm{~mL})$ and the organic phase was washed with brine $(10 \mathrm{~mL})$, dried over anhydrous $\mathrm{Na}_{2} \mathrm{SO}_{4}$ and the solvent was evaporated. The residue was purified by silica gel column chromatography using a mixture of ethyl acetate : hexane (20:80) as eluent to give the corresponding $\alpha$-hydroxy methylketone.

(士)-1-(tert-Butyldimethylsilanyloxy)-1-(4-nitrophenyl)-propan-2-one (16). $0.25 \mathrm{~g}, 80 \%$ overall yield; IR (Film) $v_{\max } / \mathrm{cm}^{-1}: 2954,2927,2858,1716,1523,1346$, 1257, 1084, 837; ${ }^{1} \mathrm{H}$ NMR (300 MHz, $\mathrm{CDCl}_{3}$ ) $\delta 0.03$ (s, $3 \mathrm{H}), 0.12(\mathrm{~s}, 3 \mathrm{H}), 0.97(\mathrm{~s}, 9 \mathrm{H}), 2.14(\mathrm{~s}, 3 \mathrm{H}), 5.12(\mathrm{~s}, 1 \mathrm{H})$, 7.62 (d, 2H, J 8.8 Hz), 8.21 (d, 2H, J 8.8 Hz); ${ }^{13} \mathrm{C}$ NMR (75 $\left.\mathrm{MHz}, \mathrm{CDCl}_{3}\right) \delta-5.01\left(\mathrm{CH}_{3}\right),-4.82,18.3,24.3,25.8,80.6$, 123.7, 126.5, 145.7, 147.7, 207.6; HRMS (70 eV, $m / z): \mathbf{M}^{+\bullet}$ calc. for $\mathrm{C}_{15} \mathrm{H}_{23} \mathrm{NO}_{4} \mathrm{Si}$ 309.13964; $\mathrm{M}^{\bullet}$ Found 309.13954.

( \pm ) - 1 -(tert-Butyldimethylsilanyloxy) - 1-(4- methanesulfonyl phenyl)-propan-2-one (17). $0.273 \mathrm{~g}, 80 \%$ overall yield; IR (Film) $v_{\max } / \mathrm{cm}^{-1}: 2954,2929,2859,1720$, 1523, 1346, 1257, 1084, 836, 544; ${ }^{1} \mathrm{H}$ NMR (300 MHz, $\left.\mathrm{CDCl}_{3}\right) \delta-0.096(\mathrm{~s}, 6 \mathrm{H}), 0.78(\mathrm{~s}, 9 \mathrm{H}), 2.25(\mathrm{~s}, 3 \mathrm{H}), 2.94(\mathrm{~s}$, $3 \mathrm{H}), 5.24$ (broad s, 1H), 7.57 (d, 2H, J $8.0 \mathrm{~Hz}), 7.84$ (d, 2H, $J 8.0 \mathrm{~Hz}) ;{ }^{13} \mathrm{C}$ NMR $\left(75 \mathrm{MHz}, \mathrm{CDCl}_{3}\right) \delta-4.76,18.4,21.7$, 26.0, 44.6, 91.3, 122.4, 126.4, 137.6, 142.1, 211.5 (C); HRMS (70 eV, $\mathrm{m} / \mathrm{z}$ ): $\mathrm{M}^{+\bullet}$ calc. for $\mathrm{C}_{16} \mathrm{H}_{26} \mathrm{O}_{4} \mathrm{SSi} 342.13211$; $\mathrm{M}^{+\bullet}$ Found 342.13209.

General procedure for the preparation of ene-carbamates 6 and 7

To stirred solutions of acids 8 or $9(1 \mathrm{mmol})$ in $10 \mathrm{~mL}$ of acetone, at $0{ }^{\circ} \mathrm{C}$, were added anhydrous triethylamine $(0.20 \mathrm{~g}, 0.26 \mathrm{~mL}, 2$ eq. $)$ and ethyl chloroformate $(0.16 \mathrm{~g}$, $0.143 \mathrm{~mL}, 1.5 \mathrm{eq}$.). The resulting solution was stirred for 15 minutes at $0{ }^{\circ} \mathrm{C}$, followed by the addition of a solution of sodium azide $(0.1 \mathrm{~g})$ in water $(0.3 \mathrm{~mL})$. After $1 \mathrm{~h}$ at $0{ }^{\circ} \mathrm{C}$, the reaction mixture was diluted with dichloromethane $(30 \mathrm{~mL})$ and the organic layer was washed with distilled water $(10 \mathrm{~mL})$, brine $(10 \mathrm{~mL})$, dried over anhydrous $\mathrm{Na}_{2} \mathrm{SO}_{4}$ and the solvent was evaporated under reduced pressure. Then, the oily residue was refluxed in anhydrous toluene $(10 \mathrm{~mL})$ for $1 \mathrm{~h}$. After this time, the solvent was removed under reduced pressure and the residue was refluxed in anhydrous $t$-butanol $(10 \mathrm{~mL})$ for $15 \mathrm{~h}$. The reaction mixture was then diluted with dichloromethane $(50 \mathrm{~mL})$ and the organic phase was washed with distilled water $(20 \mathrm{~mL})$, brine $(20 \mathrm{~mL})$ and dried over anhydrous $\mathrm{Na}_{2} \mathrm{SO}_{4}$. The solvent was evaporated and the residue was purified by silica gel column chromatography using a mixture of ethyl acetate : hexane $(5: 95)$ as eluent to give the corresponding ene-carbamates.

\{1-[(tert-Butyldimethylsilanyloxy)-(4-nitrophenyl)methyl]-vinyl\}-carbamic acid tert-butyl ester (6). $0.212 \mathrm{~g}$, $52 \%$ overall yield; IR (Film) $v_{\max } / \mathrm{cm}^{-1}: 3429,2954,2929$, 2858, 1736, 1523, 1346, 1159, 1080, 860, 841,781; ${ }^{1} \mathrm{H}$ NMR [300 MHz, $\left.\mathrm{CO}\left(\mathrm{CD}_{3}\right)_{2}\right] \delta 0.11$ (s, 3H), 0.16 (s, 3H), 0.96 (s, 9H), 1.37 (s, 9H), 4.88 (s, 1H), 5.48 (s, 1H), 5.57 (s, $1 \mathrm{H}), 6.94$ (s, exchangeable with $\left.\mathrm{D}_{2} \mathrm{O}, 1 \mathrm{H}\right), 7.76(\mathrm{~d}, 2 \mathrm{H}, J$ $7.7 \mathrm{~Hz}), 8.22(\mathrm{~d}, 2 \mathrm{H}, J 7.7 \mathrm{~Hz}) ;{ }^{13} \mathrm{C}$ NMR [75 MHz, $\left.\mathrm{CO}\left(\mathrm{CD}_{3}\right)_{2}\right] \delta-5.5,-5.4,18.2,25.5,27.7,75.2,79.4,95.5$, $123.3,127.1,142.8,147.5,149.7,152.8$; Calc. for $\mathrm{C}_{20} \mathrm{H}_{32} \mathrm{~N}_{2} \mathrm{O}_{5} \mathrm{SiC} 58.79, \mathrm{H} 7.89 \%$; Found C 58.77, H 7.89\%.

\{1 - [ ( tert-Butyldime thyls ilanyloxy) - (4 methanesulfonyl-phenyl)-methyl]-vinyl\}-carbamic acid tert-butyl ester (7). IR (Film) $v_{\max } / \mathrm{cm}^{-1}: 3429,3345,2954$, 2929, 2858, 1732, 1504, 1313, 1151, 1090, 860, 839; ${ }^{1} \mathrm{H}$ NMR (300 MHz, $\left.\mathrm{CO}\left(\mathrm{CD}_{3}\right)_{2}\right] \delta 0.11$ (s, 3H), 0.16 (s, 3H), 0.96 (s, 9H), 1.38 (s, 9H), 3.12 (s, 3H), 4.86 (s, 1H), 5.48 (s, 
$1 \mathrm{H}), 5.54(\mathrm{~s}, 1 \mathrm{H}), 6.88\left(\mathrm{~s}, 1 \mathrm{H}\right.$, exchangeable with $\left.\mathrm{D}_{2} \mathrm{O}\right)$, $7.75(\mathrm{~d}, 2 \mathrm{H}, J 8.8 \mathrm{~Hz}), 7.92(\mathrm{~d}, 2 \mathrm{H}, J 8.8 \mathrm{~Hz}) ;{ }^{13} \mathrm{C}$ NMR $[75$ $\left.\mathrm{MHz}, \mathrm{CO}\left(\mathrm{CD}_{3}\right)_{2}\right] \delta-5.5\left(\mathrm{CH}_{3}\right),-5.4\left(\mathrm{CH}_{3}\right), 18.2\left(3 \times \mathrm{CH}_{3}\right)$, $24.4\left(3 \times \mathrm{CH}_{3}\right), 27.9,44.6$, 47.9, 71.7, 79.1, 95.6, 122.9, $126.1,141.9,147.5,151.7,152.8$; Calc. for $\mathrm{C}_{21} \mathrm{H}_{35} \mathrm{NO}_{3} \mathrm{SSi}$ C 57.11 H 7.99\%; Found C 57.09 H $7.98 \%$.

General procedure for the preparation of aminoalcohols $18 a / b$ and $19 a / b$

To stirred solutions of ene carbamates 6 or 7 (1 mmol) in THF $(8 \mathrm{~mL})$, at $0{ }^{\circ} \mathrm{C}$, under nitrogen atmosphere, was slowly added a solution of $\mathrm{BH}_{3} \cdot \mathrm{S}\left(\mathrm{CH}_{3}\right)_{2}(5 \mathrm{~mL}$, conc. $1 \mathrm{~mol}$ $\mathrm{L}^{-1}$ in THF). After the addition of the borane solution, the reaction medium was warmed to room temperature and stirred for $16 \mathrm{~h}$. After that, the temperature of the resulting solution was lowered to $0{ }^{\circ} \mathrm{C}$. Then, a solution of $\mathrm{NaOH}(5$ $\mathrm{mL}$, conc. $3 \mathrm{~mol} \mathrm{~L}^{-1}$ ) was added, followed by the careful addition (drop by drop) of $30 \% \mathrm{H}_{2} \mathrm{O}_{2}(5 \mathrm{~mL})$. The mixture was stirred for 45 minutes at $0{ }^{\circ} \mathrm{C}$ and for 45 minutes more at room temperature. After this time, a saturated solution of $\mathrm{NaHCO}_{3}(10 \mathrm{~mL})$ was added and the mixture was extracted with ethyl acetate $(100 \mathrm{~mL})$. The organic layer was successively washed with a saturated solution of $\mathrm{NaHCO}_{3}(20 \mathrm{~mL})$, distilled water $(20 \mathrm{~mL})$ and brine $(20$ $\mathrm{mL}$ ) and dried over $\mathrm{Na}_{2} \mathrm{SO}_{4}$. The solvent was removed under reduced pressure. The diastereoisomers were separated by silica gel column chromatography using a mixture of ethyl acetate : hexane $(30: 70)$ as eluent.

( \pm )-Syn-[2-(tert-Butyldimethylsilanyloxy)-1hydroxymethyl-2-(4-nitrophenyl)-ethyl]-carbamic acid $t$ butyl ester (18a). $0.18 \mathrm{~g}, 65 \%$ overall yield (diastereoisomeric ratio syn : anti 2:1); IR (Film) $v_{\max } / \mathrm{cm}^{-}$ 1 3361, 3250, 2932, 2856, 1670, 1522, 1347, 1086, 839, 703; ${ }^{1} \mathrm{H}$ NMR $\left[300 \mathrm{MHz}, \mathrm{CO}\left(\mathrm{CD}_{3}\right)_{2}\right] \delta-0.12$ (s, 3H), 0.12 (s, 3H), $0.92(\mathrm{~s}, 9 \mathrm{H}), 1.27(\mathrm{~s}, 9 \mathrm{H}), 3.62(\mathrm{~m}, 2 \mathrm{H}), 3.75(\mathrm{~m}$, $1 \mathrm{H}), 3.83(\mathrm{~m}, 1 \mathrm{H}), 5.07(\mathrm{~m}, 1 \mathrm{H}), 5.77(\mathrm{~m}, 1 \mathrm{H}), 7.69(\mathrm{~d}, 2 \mathrm{H}$, $J 8.8 \mathrm{~Hz}), 8.22(\mathrm{~d}, 2 \mathrm{H}, J 8.8 \mathrm{~Hz}) ;{ }^{13} \mathrm{C}$ NMR $[75 \mathrm{MHz}$, $\left.\mathrm{CO}\left(\mathrm{CD}_{3}\right)_{2}\right] \delta:-10.0,-9.6,13.6,21.1,23.4,54.6,55.9,69.7$, 73.7, 118.7, 123.9, 143.1, 146.4, 151.0; HRMS (70 eV, $m / z): \mathrm{M}^{+\bullet}$ calc. for $\mathrm{C}_{20} \mathrm{H}_{34} \mathrm{~N}_{2} \mathrm{O}_{6} \mathrm{Si} 426.21862 ; \mathrm{M}^{+\bullet}$ Found 426.21853.

(士)-Anti-[2-(tert-Butyldimethylsilanyloxy)-1hydroxymethyl-2-(4-nitrophenyl)-ethyl]-carbamic acid tbutyl ester (18b). $0.093 \mathrm{~g}, 65 \%$ overall yield; IR (Film) $v_{\max } / \mathrm{cm}^{-1}: 3386,3257,2933,2860,1688,1347,1085,838$, $780 ;{ }^{1} \mathrm{H}$ NMR $\left[300 \mathrm{MHz}, \mathrm{CO}\left(\mathrm{CD}_{3}\right)_{2}\right] \delta-0.09$ (s, 3H), 0.14 (s, 3H), 0.93 (s, 9H), $1.27(\mathrm{~s}, 9 \mathrm{H}), 3.60(\mathrm{~m}, 2 \mathrm{H}), 3.78(\mathrm{~m}$, $1 \mathrm{H}), 3.98(\mathrm{~m}, 1 \mathrm{H}), 5.27(\mathrm{~m}, 1 \mathrm{H}), 5.65(\mathrm{~m}, 1 \mathrm{H}), 7.67(\mathrm{~d}, 2 \mathrm{H}$, $J 8.1 \mathrm{~Hz}), 8.21(\mathrm{~d}, 2 \mathrm{H}, J 8.1 \mathrm{~Hz}) ;{ }^{13} \mathrm{C}$ NMR [75 MHz, $\left.\mathrm{CO}\left(\mathrm{CD}^{3}\right)^{2}\right] \delta-9.9,-9.5,13.7,21.2,23.4,54.1,56.9,67.9$,
73.7, 118.5, 123.3, 142.8, 146.4, 150.8; HRMS (70 eV, $m / z): \mathrm{M}^{+\bullet}$ calc. for $\mathrm{C}_{20} \mathrm{H}_{34} \mathrm{~N}_{2} \mathrm{O}_{6} \mathrm{Si} 426.21862 ; \mathrm{M}^{+\bullet}$ Found 426.21859 .

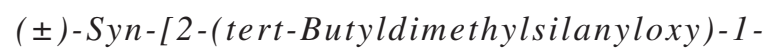
hydroxymethyl-2-(4-methanesulfonyl-phenyl)-ethyl]carbamic acid t-butyl ester (19a). $0.18 \mathrm{~g}, 65 \%$ overall yield (diastereoisomeric ratio syn : anti 1.5:1); IR (Film) $v_{\max }$ I $\mathrm{cm}^{-1}$ : 3380, 3246, 2929, 2858, 1673, 1549, 1307, 1152, 1088, 775, 562; ${ }^{1} \mathrm{H}$ NMR (300 MHz, $\left.\mathrm{CDCl}_{3}\right) \delta-0.12$ (s, $3 \mathrm{H}), 0.08$ (s, 3H), 0.90 (s, 9H), 1.42 (s, 9H), 3.10 (s, 3H), $3.43(\mathrm{~m}, 2 \mathrm{H}), 3.61(\mathrm{~m}, 1 \mathrm{H}), 3.77(\mathrm{~m}, 1 \mathrm{H}), 5.20(\mathrm{~s}, 1 \mathrm{H}), 5.43$ $(\mathrm{m}, 1 \mathrm{H}), 7.60(\mathrm{~d}, 2 \mathrm{H}, J 8.0 \mathrm{~Hz}), 7.90(\mathrm{~d}, 2 \mathrm{H}, J 8.0 \mathrm{~Hz}) ;{ }^{13} \mathrm{C}$ NMR (75 MHz, $\mathrm{CDCl}_{3}$ ) $\delta-5.2,-4.8,18.1,25.8,28.4,44.5$, 56.8, 60.7, 76.3, 79.8, 126.9, 127.2, 139.5, 147.6, 155.3; HRMS (70 eV, $\mathrm{m} / \mathrm{z}$ ): $\mathrm{M}^{+\bullet}$ calc. for $\mathrm{C}_{21} \mathrm{H}_{37} \mathrm{NO}_{6} \mathrm{SSi} 459.21109$; $\mathrm{M}^{+\bullet}$ Found 459.21100.

( \pm )-Anti-[2-(tert-Butyldimethylsilanyloxy)-1hydroxymethyl-2-(4-methanesulfonylphenyl)-ethyl]carbamic acid butyl ester (19b). $0.12 \mathrm{~g}, 65 \%$ overall yield; IR (Film) $v_{\max } / \mathrm{cm}^{-1}: 3383,551,3258,2961,2859,1688$, 1547, 1312, 1149, 1086, 859; ${ }^{1} \mathrm{H}$ NMR (300 MHz, $\left.\mathrm{CDCl}_{3}\right)$ $\delta-0.16(\mathrm{~s}, 3 \mathrm{H}), 0.07(\mathrm{~s}, 3 \mathrm{H}), 0.90(\mathrm{~s}, 9 \mathrm{H}), 1.30(\mathrm{~s}, 9 \mathrm{H}), 3.02$ (s, 3H), $3.61(\mathrm{~m}, 2 \mathrm{H}), 3.72(\mathrm{~m}, 2 \mathrm{H}), 4.92(\mathrm{~m}, 1 \mathrm{H}), 5.10(\mathrm{~m}$, 1H), 7.52 (d, 2H, J7.3 Hz), $7.88(\mathrm{~d}, 2 \mathrm{H}, J 7.3 \mathrm{~Hz}) ;{ }^{13} \mathrm{C} \mathrm{NMR}$ $\left(75 \mathrm{MHz}, \mathrm{CDCl}_{3}\right) \delta-5.1,-4.5,18.2,25.9,28.3,44.5,58.3$, 62.3, 72.4, 79.8, 127.0, 127.3, 139.3, 148.4, 155.6; HRMS $\left(70 \mathrm{eV}, \mathrm{m} / \mathrm{z}\right.$ ): $\mathrm{M}^{+\bullet}$ calc. for $\mathrm{C}_{21} \mathrm{H}_{37} \mathrm{NO}_{6} \mathrm{SSi} 459.21109 ; \mathrm{M}^{+}$ Found 459.21100.

General procedure for the preparation of aminodiols 4 and 5

To stirred solutions of the syn diastereoisomers 18a or 19a $(0.2 \mathrm{mmol})$ in $4 \mathrm{~mL}$ of ethyl acetate, at room temperature, was added a solution of hydrochloric acid (4 $\mathrm{mL}$, conc. $\left.6 \mathrm{~mol} \mathrm{~L}^{-1}\right)$. After $3 \mathrm{~h}$, the resulting solution was extracted twice with ethyl ether $(30 \mathrm{~mL})$ and the ethereal phase was separated. The temperature of the aqueous layer was lowered to $0{ }^{\circ} \mathrm{C}$ and the $\mathrm{pH}$ was adjusted to 7-8 with solid $\mathrm{NaHCO}_{3}$. The slightly basic aqueous phase was sucessively extracted with ethyl acetate $(5 \times 30 \mathrm{~mL})$. Then, the organic phases were combined and dried over anhydrous sodium sulfate and the solvent was removed under reduced pressure. The residue was purified by ion exchange chromatography column on Dowex.

(士)-Syn-2-Amino-1-(4-nitrophenyl)-propane-1,3-diol (4). $0.041 \mathrm{~g}, 98 \%$ yield; IR (Film) $v_{\max } / \mathrm{cm}^{-1}: 3407,3283$, 2985, 2902, 1515, 1603, 1353, 1047, 855; ${ }^{1} \mathrm{H}$ NMR [300 $\left.\mathrm{MHz}, \mathrm{CO}(\mathrm{CD} 3)_{2}\right] \delta 3.10(\mathrm{~d}, J 8.1 \mathrm{~Hz}, 1 \mathrm{H}), 3.76(\mathrm{~m}, 2 \mathrm{H})$, $4.81(\mathrm{~m}, 1 \mathrm{H}), 7.67$ (d, J 8.7Hz, 2H), 8.20 (d, J 8.7Hz, 2H); ${ }^{13} \mathrm{C}$ NMR $\left[75 \mathrm{MHz}, \mathrm{CO}\left(\mathrm{CD}_{3}\right)_{2}\right] \delta$ 54.7, 63.9, 75.0, 118.9, 
122.6, 142.9, 147.4; Calc. for $\mathrm{C}_{9} \mathrm{H}_{12} \mathrm{~N}_{2} \mathrm{O}_{4} \mathrm{C} 59.94$, H 5.70\%; Found C 59.92, H 5.70\%.

(士)-Syn-2-Amino-1-(4-methanesulfonyl)-propane-1,3diol (5). $0.044 \mathrm{~g}, 90 \%$ yield; IR (Film) $v_{\max } / \mathrm{cm}^{-1}: 3362$, 2929, 1406, 1296, 1147, 1088, 961, 772; ' $\mathrm{H}$ NMR [300 $\left.\mathrm{MHz}, \mathrm{CO}\left(\mathrm{CD}_{3}\right)_{2}\right] \delta 3.30(\mathrm{~m}, 1 \mathrm{H}), 3.32(\mathrm{~s}, 3 \mathrm{H}), 3.97(\mathrm{~m}, 2 \mathrm{H})$, 4.99 (d, $J 3.8 \mathrm{~Hz}, 1 \mathrm{H}), 7.87$ (d, J 9.3Hz, 2H), 8.12 (d, $J$ 9.3Hz, 2H); ${ }^{13} \mathrm{C} \mathrm{NMR}\left[75 \mathrm{MHz}, \mathrm{CO}\left(\mathrm{CD}_{3}\right)_{2}\right] \delta 39.3,54.6$, 63.8, 75.1, 122.4, 122.8, 135.7, 143.9; Calc. for $\mathrm{C}_{10} \mathrm{H}_{15} \mathrm{NO}_{4} \mathrm{~S}$ C 48.96, H 6.16\%; Found C 48.85, H 6.14\%.

Synthesis of (土)-chloramphenicol (1)

A stirred solution of aminodiol 4 (0.04 g, $0.2 \mathrm{mmol})$ in methyl dichloroacetate $(10 \mathrm{~mL})$ was refluxed for $3 \mathrm{~h}$. After that time, the temperature of the reaction solution was lowered to room temperature and the solvent was removed under reduced pressure. The crude residue was purified by silica gel column chromatography using a mixture of acetone : ethyl acetate (10:90) to provide ( \pm )-chloramphenicol (1) as a white solid $(0.05 \mathrm{~g}, 79 \%)$. mp 149-150 ${ }^{\circ} \mathrm{C}$ (Lit. ${ }^{7} 148$ $\left.150^{\circ} \mathrm{C}\right) ; \mathrm{IR}(\mathrm{KBr}) v_{\max } / \mathrm{cm}^{-1}: 3390,2924,2856,1678,1518$, 1348, 1044, 811; ${ }^{1} \mathrm{H}$ NMR [500 MHz, $\left.\mathrm{CO}\left(\mathrm{CD}_{3}\right)_{2}\right] \delta 3.76(\mathrm{~m}$, $2 \mathrm{H}), 4.17(\mathrm{~m}, 1 \mathrm{H}), 4.30(\mathrm{~m}, 1 \mathrm{H}), 5.25(\mathrm{~s}, 1 \mathrm{H}), 5.33(\mathrm{~s}, 1 \mathrm{H})$, 6.35 (s, 1H), 7.55 (m, 1H), 7.70 (d, 2H, J7.6 Hz), 8.18 (d, 2H, $J 7.6 \mathrm{~Hz}) ;{ }^{13} \mathrm{C} \mathrm{NMR}\left[75 \mathrm{MHz}, \mathrm{CO}\left(\mathrm{CD}_{3}\right)_{2}\right] \delta 52.8,57.1,62.3$, 66.0, 118.5, 122.8, 142.7, 146.0, 159.2; HRMS (70 eV, $\mathrm{m} / \mathrm{z}$ ): $\mathrm{M}^{+}$Calc. for $\mathrm{C}_{11} \mathrm{H}_{12} \mathrm{Cl}_{2} \mathrm{~N}_{2} \mathrm{O}_{5} 322.01233$; Found 322.01230.

\section{Synthesis of (土)-fluoramphenicol (2)}

A stirred solution of aminodiol 4 (0.02 g, $0.1 \mathrm{mmol})$ in methyl difluoroacetate $(5 \mathrm{~mL})$ was refluxed for $4 \mathrm{~h}$. After that time, the temperature of the reaction solution was lowered to room temperature and the solvent was removed under reduced pressure. The crude residue was purified by silica gel column chromatography using a mixture of acetone: ethyl acetate $(10: 90)$ to provide ( \pm )-Fluoramphenicol (2) as a white solid $(0.024 \mathrm{~g}, 85 \%)$, m.p. $152-153{ }^{\circ} \mathrm{C}$; IR (KBr) $v_{\max } / \mathrm{cm}^{-1}: 3787,2924,2859,1690,1518,1349,1070,851$; ${ }^{1} \mathrm{H} \mathrm{NMR}\left[500 \mathrm{MHz}, \mathrm{CO}\left(\mathrm{CD}_{3}\right)_{2}\right] \delta 3.78(\mathrm{~m}, 2 \mathrm{H}), 4.06(\mathrm{~m}, 1 \mathrm{H})$, $4.25(\mathrm{~m}, 1 \mathrm{H}), 5.33(\mathrm{~s}, 2 \mathrm{H}), 6.08\left(\mathrm{t}, 1 \mathrm{H},{ }^{2} J 54.2 \mathrm{~Hz}\right), 7.56(\mathrm{~m}$, 1H), $7.71(\mathrm{~d}, 2 \mathrm{H}, J 8.8 \mathrm{~Hz}), 8.21(\mathrm{~d}, 2 \mathrm{H}, J 8.8 \mathrm{~Hz}) ;{ }^{13} \mathrm{C} \mathrm{NMR}$ $\left[75 \mathrm{MHz}, \mathrm{CO}\left(\mathrm{CD}_{3}\right)_{2}\right] \delta$ 57.0, 61.8, 70.9, 109.0, 123.4, 127.6, 147.5, 150.8, 162.6; HRMS (70 eV, $\mathrm{m} / \mathrm{z}): \mathrm{M}^{+\bullet}$ Calc. for $\mathrm{C}_{11} \mathrm{H}_{12} \mathrm{~F}_{2} \mathrm{~N}_{2} \mathrm{O}_{5}$ 290.07143; Found 290.07139.

Synthesis of (土)-thiamphenicol (3)

A stirred solution of aminodiol $5(0.025 \mathrm{~g}, 0.1 \mathrm{mmol})$ in methyl dichloroacetate $(5 \mathrm{~mL})$ was refluxed for $1 \mathrm{~h}$. After that time, the temperature of the reaction solution was lowered to room temperature and the solvent was removed under reduced pressure. The crude residue was purified by silica gel column chromatography using a mixture of acetone : ethyl acetate $(10: 90)$ to provide $( \pm)$-thiamphenicol (3) as a white solid (0.024 g, 65\% ). m.p. $164-164.5^{\circ} \mathrm{C}$ (Lit. ${ }^{19}$ $164.3-166.5^{\circ} \mathrm{C}$ ); IR (KBr) $v_{\max } / \mathrm{cm}^{-1}: 3396,2922,2853$, $1675,1523,1343,1288,1145,1062,816 ;{ }^{1} \mathrm{H}$ NMR [500 $\left.\mathrm{MHz}, \mathrm{CO}\left(\mathrm{CD}_{3}\right)_{2}\right] \delta 3.09(\mathrm{~s}, 3 \mathrm{H}), 3.76(\mathrm{~m}, 2 \mathrm{H}), 4.07(\mathrm{~m}, 1 \mathrm{H})$, $4.17(\mathrm{~m}, 1 \mathrm{H}), 5.31(\mathrm{~s}, 1 \mathrm{H}), 6.21(\mathrm{~s}, 1 \mathrm{H}), 6.39(\mathrm{~s}, 1 \mathrm{H}), 7.56(\mathrm{~m}$, 1H), 7.70 (d, 2H,J $8.5 \mathrm{~Hz}), 7.90$ (d, $2 \mathrm{H}, J 8.5 \mathrm{~Hz}) ;{ }^{13} \mathrm{C} \mathrm{NMR}$ [75 MHz, $\left.\mathrm{CO}\left(\mathrm{CD}_{3}\right)_{2}\right] \delta 39.3,52.7,56.9,62.3,66.1,122.5$, 135.7, 144.2, 159.0; HRMS (70 eV, $\mathrm{m} / \mathrm{z}$ ): $\mathrm{M}^{+\bullet}$ Calc. for $\mathrm{C}_{12} \mathrm{H}_{15} \mathrm{Cl}_{2} \mathrm{NO}_{5} \mathrm{~S}$ 355.00480; Found 355.00455.

\section{Acknowledgments}

The authors thank Fapesp for a fellowship to CRM (01/01558-8) and for financial support (02/00461-3) and CNPq (301369/1989-9) for a research fellowship to FC. The authors are grateful to Prof. C. H. Collins for English corrections of this manuscript.

\section{References}

1. Aguilar, L.; Gimenez, M. J.; Garcia-Rey, C.; Martin, J. E.; J. Antimicrob. Chemother. 2002, 50, 93.

2. Lautenbach, E.; Gould, C. V.; La Rosa, L. A.; Marr, A. M.; Fishman, N. O.; Becker, W. B.; Nachamkin, I.; Int. J. Antimicrob. Agents 2004, 23, 200; Boulos, A.; Rolain, J. M.; Raoult, D.; Antimicrob. Agents. Chemother. 2004, 48, 747; Zhanel, G. G.; Laing, N. M.; Nichol, K. A.; Palatvek, L. P.; Noreddin, A.; Hisanaga, T.; Johnson, J. L.; Hoban, D. J.; J. Antimicrob. Chemother. 2003, 52, 382; Cunrie, B. J.; Eur. Respi. J. 2003, 22, 542.

3. Xaplanteri, M. A.; Andreou, A.; Dinos, G. P.; Kalpaxis, D. L.; Nucleic Acids Res. 2003, 32, 5074; Isenberg, S. J.; J. AAPOS 2003, 7, 307.

4. Ungheri, D.; Licciardello, L.; PCT Int. Appl. WO 060344, 2001 (CA 135:162487); Colombo, G.; Ungheri, D.; Licciardello, L.; Giromondo, M.; Drago, L. PCT Int. Appl. WO 076585, 2001 (CA 135: 198756).

5. Ehrlich, J.; Bartz, Q. R.; Smith, R. M.; Joslyn, D. A.; Burkholder, P. R.; Science 1947, 106, 417; Bartz, Q.R.; J. Biol. Chem. 1948, 172, 445; Smith, R. M.; Joslyn, D. A.; Gruhzit, O. M.; McLean, W. I.; Penner, M. A.; Ehrlich, J.; J. Bacteriol. 1948, 55, 425; Bartz, Q.R.; J. Clin. Invest. 1949, 28, 1051.

6. For examples of classical industrial synthesis of chloramphenicol and related antibiotics, see: Ehrlich, J.; KirkOthmer Encyclopedia of Chemical Technology, John Wiley \& Sons: New York, 1978, vol. 2., p. 920. 
7. For some syntheses of racemic chloramphenicol, see: Controulis, J.; Rebstock, M. C.; Crooks, Jr., H. M.; J. Am. Chem. Soc. 1949, 71, 2463; Long, L. M.; Troutman, H. D.; J. Am. Chem. Soc. 1949, 71, 2469 and 2473; Ehrhart, G.; Siedel, W.; Nahm, H.; Chem. Ber. 1957, 90, 2088; Horak, V.; Moezik, F.; Klein, R. F. X.; Giordano, C.; Synthesis 1984, 839; Hazra, B. G.; Pore, V. S.; Maybhate, S. P.; Synth. Commun. 1997, 27 , 1857.

8. For some chiral syntheses of chloramphenicol and fluoramphenicol, see: Chenevert, R.; Thiboutot, S.; Synthesis 1989, 444; Schollkopf, U.;Beulshausen, T.; Liebigs Ann. Chem. 1989, 223; Rao, A. V. R.; Rao, S. P.; Bhanu, M. N.; J. Chem. Soc., Chem.Commun. 1992, 859; Lou, B.-L.; Zhang, Y.-Z.; Dai, L.-X.; Chem. Ind. 1993, 7, 249; Easton, C. J.; Hutton, C. A.; Merrett, M. C.; Tiekink, E. R. T.; Tetrahedron 1996, 52, 7025; Veeresa, G.; Datta, A.; Tetrahedron Lett. 1998, 39, 8503; Corey, E. J.; Choi, S.; Tetrahedron Lett. 2000, 41, 2765; Park, J. N.; Ko, S. Y.; Koh, H. Y.; Tetrahedron Lett. 2000, 41, 5553; Loncaric, C.; Wulff, W. D.; Org. Lett. 2001, 3, 3675; Baskhar, G.; Kumar, V.S.; Rao, B.V.; Tetrahedron:Asymmetry 2004, 15, 1279.

9. For some racemic syntheses of thiamphenicol, see: McCombie, S. W.; Nagabhushan, T. L.; Tetrahedron Lett. 1987, 28, 5395; Giordano, C.; Cavicchioli, S.;Levi, S.; Villa, M.; Tetrahedron Lett. 1988, 29, 5561.

10. For some asymmetric syntheses of thiamphenicol and florfenicol, see: Giordano, C.; Cavicchioli, S.; Levi, S.; Villa, M.; J. Org. Chem. 1991, 56, 6114; Davis, F. A.; Zhou, P.; Tetrahedron Lett. 1994, 35, 7525; Wu, G.-Z.; Tormos, W. I.; PTC Int. Appl.WO 94/14764, 1994 (CA 121: 133722); Gennari, C.; Pain, G.; Tetrahedron Lett. 1996, 37, 3747; Wu, G.-Z.; Schumacher, D. P.; Tormos, W.; Clark, J. E.; Murphy, B. L.; J. Org. Chem. 1997, 62, 2996; Gennari, C.; Vulpetti, A.; Pain, G.; Tetrahedron 1997, 53, 5909; Kaptein, B.;Dooren, T. J. G. M. V.; Boesten, W. H. J.; Sonke, T.; Duchateau, A. L. L.; Broxterman, Q. B.; Kamphuis, J.; Org. Process Res. Dev. 1998, 2, 10; Nagabhushan, T.L.; U. S. Patent 4235 892, 1980 (CA 94: 139433).

11. Rossi, R.C.; Coelho, F.; Tetrahedron Lett. 2002, 43, 2797.

12. Coelho, F.; Veronese, D.; Lopes, E.C.S.; Rossi, R.C.; Tetrahedron Lett. 2003, 44, 5731.

13. For comprehensive reviews on the Baylis-Hillman reaction see: Basavaiah, D.; Rao, A. J.; Satyanarayama, T.; Chem. Rev. 2003, 103, 811; Almeida, W. P.; Coelho, F.; Quim. Nova 2000, 23, 98 (CA 132: 236562e); Ciganek, E.; Org. React. 1997, 51, 201; Basavaiah, D.; Rao, P. D.;. Hyma, R. S.; Tetrahedron 1996, 52, 8001. For some new insights about the mechanism of the Baylis-Hillman reaction see: Santos, L.S.; Pavam, C.H. Almeida, W.P.; Coelho, F.; Eberlin, M.N.; Angew. Chem. Int. Ed. 2004, 43, 4330.
14. For some examples of the application of Baylis-Hillman adducts as starting material for the synthesis of natural products see: Almeida, W. P.; Coelho, F.; Tetrahedron Lett. 2003, 44, 937; Feltrin, M. A.; Almeida, W. P.; Synth. Commun. 2003, 33, 1141; Mateus, C. R.; Feltrin, M. P.; Costa, A. M.; Coelho, F.; Almeida, W. P.; Tetrahedron 2001, 57, 6901; Iwabuchi, Y.; Furukawa, M.; Esumi, T.; Hatakeyama, S.; Chem. Commun. 2001, 2030; Iwabuchi, Y.; Sugihara, T.; Esumi, T.; Hatakeyama, S.; Tetrahedron Lett. 2001, 42, 7867; Masunari, A.; Trazzi, G.; Ishida, E.; Coelho, F.; Almeida, W. P.; Synth. Commun. 2001, 31, 2100; Ameer, F.; Drewes, S. E.; Houston-McMillan, M. S.; Kaye, P.T.; S. Afr. J. Chem. 1986, 39, 57; Hofmann, H. M. R.; Rabe, J.; Helv. Chim. Acta 1984, 67, 413; Hofmann, H. M. R.; Rabe, J.; J. Org. Chem. 1985, 50, 3849; Drewes, S. E.; Emslie, N. D.; J. Chem. Soc. Perkin Trans. 1 1982, 2079.

15. Bergmeier, S.C.; Tetrahedron 2000, 56, 2561 and references cited therein; Gonzalez-Resende, M.E.; Jorda-Gregori, M.E.; Sepulveda-Arques, J.; Orena, M.; Tetrahedron:Asymmetry 2004, 15, 419 and references cited therein; Beardsley, D. A.; Fisher, G. B.; Goralski, C. T.; Nicholson, L. W.; Singaram, B.; Tetrahedron Lett. 1994, 35, 1511; Moody, M. H.; Kaptein, B.; Broxterman, Q. B.; Boesten, W. H. J.; Kamphuis, J.; Tetrahedron Lett. 1994, 35, 1777; Sasai, H.; Kim, W.; Suzuki, T.; Shibasaki, M.; Tetrahedron Lett. 1994, 35, 6123.

16. Almeida, W. P.; Coelho, F. Tetrahedron Lett. 1998, 39, 8609; Coelho, F.; Almeida, W. P.; Mateus, C. R.; Veronese, D.; Lopes, E. C. S.; Silveira, G. P. C.; Rossi, R. C.; Pavam, C. H.; Tetrahedron 2002, 58, 7437.

17. Braibante, M.E.F.; Braibante, H.S.; Costenaro, J.H.; Synthesis 1999, 943; van Well, R.M.; Overkleeft, H.S.; van Boom, J.H.; Coop, J.H.; Wang, J.B.; Wang, N.Y.; van der Marel, G.A.; Overhand, M.; Eur. J. Org. Chem. 2003, 9, 1704; Kedrowski, B.L.; J. Org. Chem. 2003, 68, 5403; Lu, Y.H.; Taylor, R.T.; Heterocycles 2004, 62, 869; O'Connor, P.D.; Mander, L.N.; McLachlan, N.W.; Org. Lett. 2004, 6, 703.

18. Jackson, R.F.W.; Standen, S.P.; Clegg, W.; McCamley, A.; Tetrahedron Lett. 1992, 33, 6197 and references cited therein; Hoffmann, R.W.; Chem. Rev. 1989, 89, 1841; Kahn, S.D.; Pau, C.F.; Chamberlin, A.R.; Hehre, W. J.; J. Am. Chem. Soc. 1987, 109, 650 and references cited therein; Coelho, F.; Almeida, W. P.; Mateus, C. R.; Furtado, L. D.; Gouveia, J. C. F.; ARKIVOC 2003, X, 443; Mateus, C.R.; Almeida, W. P.; Coelho, F.; Tetrahedron Lett. 2000, 41, 2533.

19. Cutler, R.A.; Stenger, R.J.; Suter, C.M.; J. Am. Chem. Soc. 1952, 74, 5475.

20. For some examples of carbamates prepared from BaylisHillman adducts, see: Ciclosi, M.; Fava, C.; Galeazzi, R.; Orena, M.; Sepulveda-Arques, J.; Tetrahedron Lett. 2002, 43, 2199; Mamaghami, M.; Badrian, A.; Tetrahedron Lett. 2004, 45, 1547; Xu, L. W.; Xia, C. G.; Tetrahedron Lett. 2004, 45, 4507. 
21. For some industrial strategies for the resolution of racemic mixtures of chloramphenicol and for the inversion of of $(2 S$, $3 S$ ) enantiomer, see: Coppi, L.; Giordano, C.; Langoni, A.; Panossian, S. In Chirality in Chemistry II; Collins, A. N.; Sheldrake, G. N; Crosby, J., eds., Wiley: Chichester, 1997, p. 353-362; Dick, H.; Gradel, W. -D.; Weber, M.; D.E. Patent 3543021, 1987 (CA 107: 197794).
22. Iwabuchi, Y.; Nakatami, M.; Yokoyama, N.; Hatakeyama, S.; J. Am. Chem. Soc. 1999, 121, 10219.

Received: September 21, 2004 Published on the web: March 15, 2005

FAPESP helped in meeting the publication costs of this article. 